\title{
Disturbances of micronutrient and antioxidant status in diabetes
}

\author{
B Y J. J. STRAIN \\ Human Nutrition Research Group, University of Ulster, Coleraine BT52 ISA, Northern Ireland
}

Oxidants or reactive oxygen species (ROS) have been implicated in the pathology of a number of human diseases including insulin-dependent diabetes mellitus (IDDM) and non-isulin-dependent diabetes mellitus (NIDDM). Sato et al. (1979) were the first to report increased levels of plasma thiobarbituric acid-reactive substances (TBARS), a putative measure of ROS-induced lipid peroxidative damage, in IDDM and NIDDM patients. Subsequent studies have confirmed this observation of increased lipid peroxides in blood from NIDDM (Kaji et al. 1985; Uzel et al. 1987) and IDDM (Jongkind et al. 1989) patients and in various tissues from rats with streptozotocin (STZ)- or alloxaninduced diabetes (Higuichi, 1982; Karpen et al. 1982; Matkovics et al. 1982).

The possibility that the long-term complications of diabetes are associated with increased ROS-mediated damage is also supported by the work of Sato et al. (1979) who found higher plasma TBARS in diabetic patients with angiopathy compared with those without angiopathy. Moreover, increased lipid peroxide levels were also found in lenses of both diabetic patients (Costagliola et al. 1988) and STZ-induced diabetic rats (Yeh \& Ashton, 1990).

The elevated levels of lipid peroxides in diabetes could result from the hyperglycaemic state as there is a significant relationship between erythrocyte membrane lipid peroxidation and hyperglycaemia in diabetic patients (Jain et al. 1989) and plasma lipid peroxides are higher in poorly-controlled compared with well-controlled diabetic patients (Sato et al. 1979). Jain et al. (1990) found that the increase in TBARS in erythrocytes from STZ-induced diabetic rats could be prevented in those rats in which hyperglycaemia was controlled by insulin treatment. Further indications that complications of diabetes associated with elevated levels of apparently oxidative changes to proteins and lipids are reviewed by Baynes (1991). It has been suggested that increased generation of ROS may arise from transition-metal catalysed autoxidation of glucose and other small autoxidizable molecules (Hunt \& Wolff, 1990) or oxidation of glycated proteins (Gillery et al. 1989; Mullarkey et al. 1990). These mechanisms may explain the increased lipid peroxidation associated with hyperglycaemia.

Alternatively, increased ROS-mediated lipid peroxidation in diabetes may result from disturbances in antioxidant defence. There is now ample evidence of substantial and complex antioxidant enzyme alterations in experimental and clinical diabetes (Godin et al. 1988), although results from different laboratories are not consistent (Oberley, 1988; Asayama et al. 1989). Some of the inconsistent observations of antioxidant enzymes in diabetes could arise from inter alia effects of starvation (Wohaieb \& Godin, 1987) or ageing (Cand \& Verdetti, 1989) on these enzymes.

\section{NIACIN AND RIBOFLAVIN}

A role for ROS in the aetiology of diabetes has been proposed by Okamoto (1983) in a model for $\beta$ cell damage. This model postulates a common final pathway for the toxic 


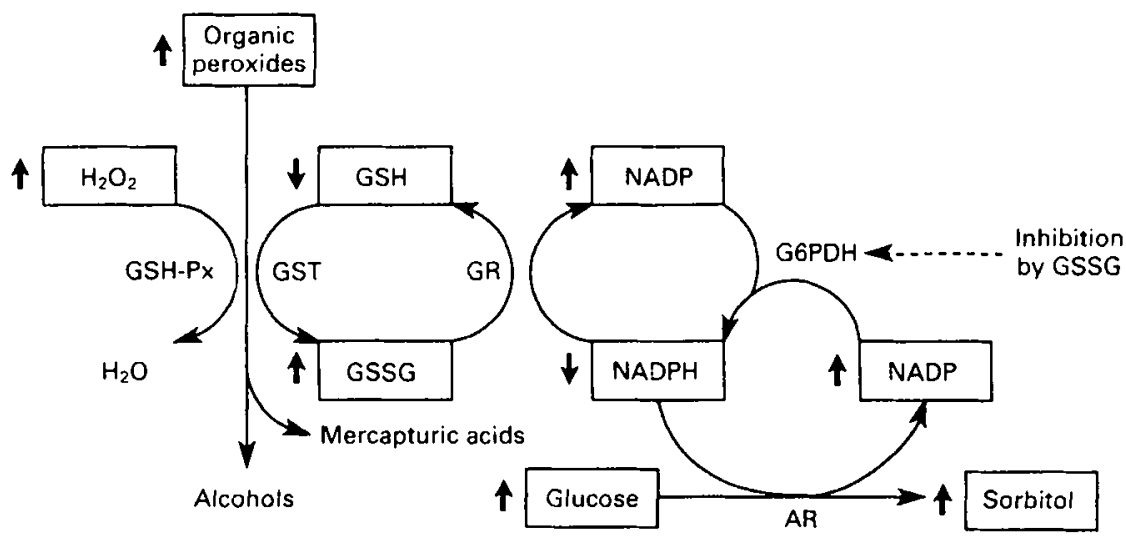

Fig. 1. Effect of competition between aldose reductase (EC 1.1.1.21; (AR)) and glutathione reductase (EC 1.6.4.2; (GR)) for NADPH. G6PDH, glucose-6-phosphate dehydrogenase (EC 1.1.1.49); GSH, reduced glutathione: GSH-Px, glutathione peroxidase (EC 1.11.1.9); GSSG, oxidized glutathione; GST, glutathione-Stransferase ( $E C$ 2 2.5.1.18).

effect of agents such as alloxan, STZ, radiation, viruses, and inflammatory tissue damage through the involvement of ROS in breakage of nuclear DNA. The DNA damage initiates the repair process in which the enzyme poly (ADP-ribose) synthetase ( $E C$ 6.5.1.2) becomes activated. Cellular NAD is used as a source of ADP-ribose for DNA repair and this results in a sharp fall in intracellular levels of NAD. The combined effect of the non-physiological levels of NAD and ROS-mediated mitochondrial damage is considered to result in a fall in ATP levels and subsequently a fall in insulin release (Hellerstrom et al. 1986). Administration of nicotinamide or poly (ADP-ribose) synthetase inhibitors can maintain $\beta$ cell function after exposure to diabetogenic agents alloxan and STZ (Okamoto, 1983).

Reasons why $\beta$ cells of the pancreas should be most vulnerable to these agents are presently unclear. Oberley (1988) has suggested that uptake, metabolism, and antioxidant status of the $\beta$ cell may all be involved in the selective toxicity of alloxan, with the most conclusive evidence favouring a major role for ROS. The oxidative basis of the selective toxicity of STZ for the $\beta$ cell, however, is less clear as an alkylation mechanism appears to be involved in the DNA strand breaks. Nevertheless it is probable that increased levels of ROS are involved in STZ action through an interference with glutathione (GSH) metabolism (Oberley, 1988). The central role of GSH and its relationship with the phosphorylated form of NAD and with the polyol pathway in diabetes is given in Fig. 1. Aldose reductase ( $E C$ 1.1.1.21) inhibitors which can inhibit depletion of GSH can prevent lipid peroxidation of rat lens resulting from insulin deficiency (Yeh \& Ashton, 1990).

Abnormalities in GSH metabolism are a feature of diabetes; for example, Murakami et al. (1989) found that the decrease in GSH in erythrocytes of diabetic patients was brought about by impaired GSH synthesis and that the increase in oxidized GSH (GSSG) was brought about by the decreased transport of GSSG through the erythrocyte membrane together with a decrease in glutathione reductase ( $E C$ 1.6.4.2; GR) activity. Gebre-Medhin et al. (1982), however, have reported increased GR activity in IDDM children. Perhaps inconsistencies in GR activity reported in the literature can be 


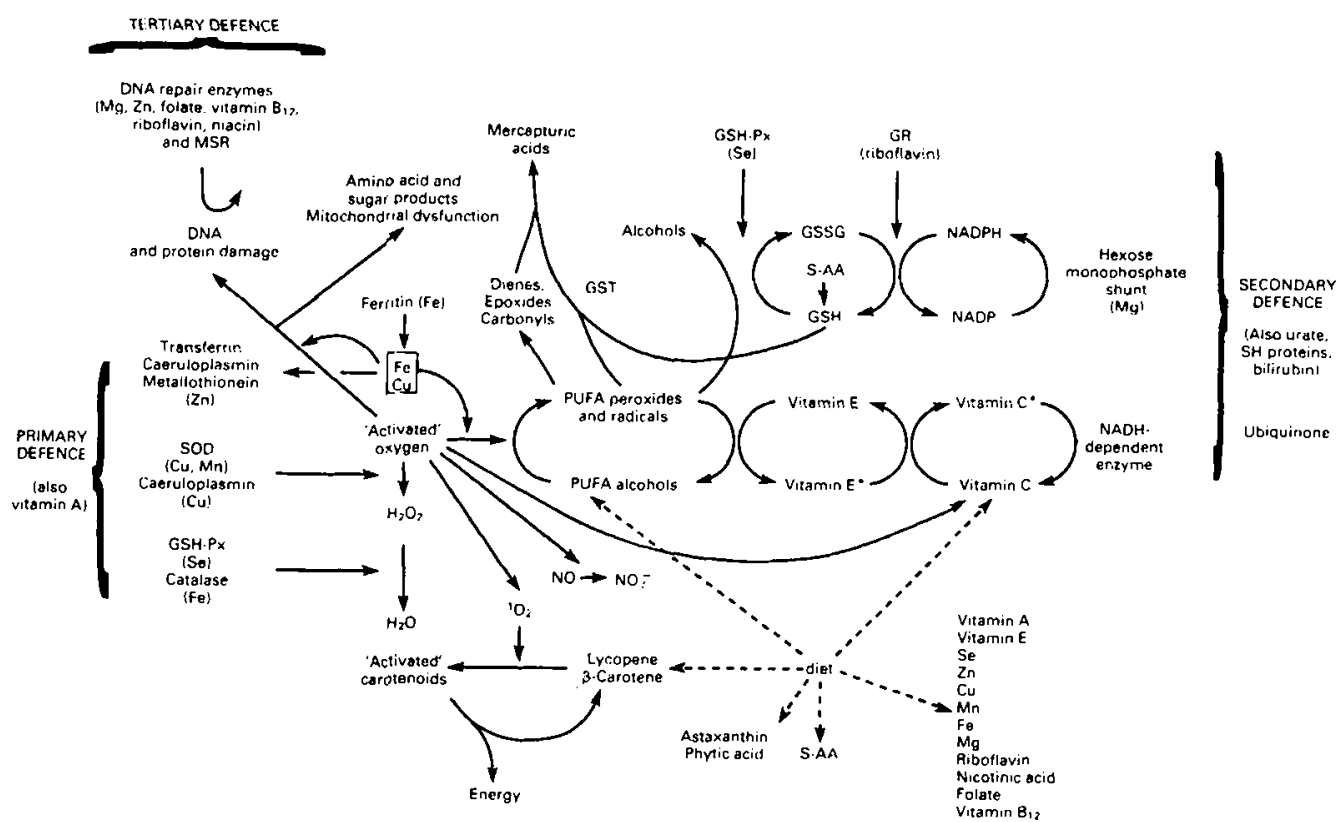

Fig. 2. Antioxidant defence system (after Strain et al. 1991). GR. glutathione reductase (EC 1.6.4.2); GSH, reduced glutathione: GSH-Px, glutathione peroxidase (EC 1.11.1.9); GSSG, oxidized glutathione; GST, glutathione-S-transferase (EC 2.5.1.18); MSR, methionine sulphoxide reductase (EC 1.8.4.5): PUFA, polyunsaturated fatty acids; S-AA, sulphur amino acids; SH-proteins, sulphydryl proteins; SOD, superoxide dismutase $(E C$ 1.15.1.1): $\mathrm{Fe}$, transition metal-catalysed oxidant damage to biomolecules.

explained by differences in riboflavin (a co-factor needed for GR activity) status. For example Cole et al. (1976) have demonstrated decreased GR activities in IDDM children which could be restored by dietary riboflavin supplementation.

Whatever the precise nature of the toxic effects of alloxan or STZ, $\beta$ cells appear to be defective in handling ROS compared with most other body tissues. Antioxidant agents such as the antioxidant enzymes can prevent or ameliorate the toxic effects of alloxan or STZ on $\beta$ cells (Okamoto, 1983; Oberley, 1988).

Two important animal models for IDDM are the non-obese diabetic mouse (NOD) and the BB rat. In both these models spontaneous diabetes develops via immunological mechanisms. Diabetes can be prevented by treatment of animals with nicotinic acid or desferrioxamine, or both (Nomikos et al. 1986) and can be ameliorated with the cholesterol-lowering drug of known antioxidant properties, Probucol (Drash et al. 1988).

Fig. 2 shows the role of niacin, riboflavin, and other micronutrients in antioxidant defence. Obviously many of these nutrients have myriad biological roles distinct from antioxidant defence. For conceptual convenience antioxidant defences have been classified as a primary defence which is concerned with limiting the production of new ROS through the activity of such enzymes as superoxide dismutase (EC 1.15.1.1; SOD), glutathione peroxidase (EC 1.11.1.9; GSH-Px), catalase ( $E C$ 1.11.1.6) and caeruloplasmin $(E C$ 1.16.3.1). Further protection is provided by caeruloplasmin, transferrin, lactoferrin, and other metal-binding proteins which act as primary antioxidants by limiting the availability of free ferrous or cuprous ions and, hence, decreasing formation 
of the hydroxyl radical, regarded as the most highly reactive of the primary oxidants (Halliwell, 1987).

Secondary antioxidants trap ROS directly to prevent amplification of radical formation and, thus, act as disrupters of free-radical chain reactions. Further antioxidant defence, the tertiary defence system, includes enzymes capable of repairing previous oxidant damage to important biomolecules (Fig. 2).

\section{IRON}

The use of the Fe-chelator desferrioxamine to prevent inflammatory tissue damage in NOD mice (Nomikos et al. 1986) indicates that Fe might be catalysing the formation of hydroxyl radicals via the Fenton reaction (see Strain et al. 1991) in $\beta$ cells. Thus, conditions of $\mathrm{Fe}$ overload in various tissues, including the pancreas, might precipitate the destruction of the $\beta$ cell leading to the onset of diabetes via a ROS mechanism. Indeed there are strong links between increased Fe status and diabctes. Overt diabetes occurs in about $60 \%$ of patients with idiopathic haemochromatosis (Powell, 1985). While the prevalence of idiopathic haemochromatosis in the general population is $2-5 / 1000$, the prevalence of previously unrecognized idiopathic haemochromatosis among diabetic patients was $9 \cdot 6 / 1000$ (Phelps et al. 1989). Insulin resistance is markedly improved after depletion of body Fe stores by phlebotomy, resulting in lower insulin requirements in those patients with IDDM and improvement in glucose tolerance in about $50 \%$ of patients with NIDDM (Stremmel et al. 1987).

Glucose intolerance and overt diabetes are also observed in secondary forms of Fe-loading disease. Merkel et al. (1988) suggested that insulin resistance and increased insulin secretion develop in older children with thalassaemia treated with long-term hypertransfusion therapy before the development of diabetes. Apart from impaired insulin secretion caused by selective deposition of $\mathrm{Fe}$ in $\beta$ cells of the pancreas, other possible mechanisms which may explain these findings include the development of insulin resistance due to $\mathrm{Fe}$ accumulation in the liver and muscle. It is tempting to speculate that the increased Fe status in obese women (Fricker et al. 1990) and those with greater body mass index (Micozzi et al. 1989) might give increased risk of NIDDM. Although associated with increased serum triacylglycerols, Fe deficiency does not secm to have a significant effect on glucose homeostasis (Mertz, 1982).

Diabetes is also associated with abnormalities in Fe metabolism. In experimental STZ-induced diabetic rats, Fe content was increased in liver, kidney and femur (Johnson \& Evans, 1984) and in muscle but was decreased in the duodenum compared with control rats fed on equivalent quantities of Fe (Failla \& Kiser, 1981). The acute diabetogenic action of STZ in rats results in greater hepatic Fe and lower serum Fe levels (McDermott et al. 1991). These defects in Fe metabolism may result in decreased Fe transfer to the fetus during late gestation in diabetic mothers and may partially explain the abnormal $\mathrm{Fe}$ distribution in infants of diabetic mothers (Georgieff et al. 1990).

\section{COPPER}

Like $\mathrm{Fe}, \mathrm{Cu}$ can catalyse ROS formation in in vitro systems and much of the primary antioxidant defence is involved in ensuring that $\mathrm{Cu}$ is unavailable for such reactions (Fig. 2). Unlike Fe, however, no satisfactory explanation has been proposed for the liberation 
of free cuprous ions in vivo (cf. superoxide liberation of ferrous species from ferritin, Biemond et al. 1988). In contrast the evidence for an important role for $\mathrm{Cu}$ in antioxidant defences through maintaining caeruloplasmin and $\mathrm{Cu}, \mathrm{Zn}-\mathrm{SOD}$ activities has accumulated since the pioneering work of Paynter (1980) who found that dietary $\mathrm{Cu}$ and manganese deficiencies, or both, were associated with increased susceptibility of rat heart mitochondria to oxidant damage as measured by TBARS. Direct evidence of increased lipid peroxidation in tissues from $\mathrm{Cu}$-deficient rats have been provided by other workers (Balevska et al. 1981; Lynch \& Strain, 1989; Wachnik et al. 1989; Strain \& Lynch, 1990) while Lawrence \& Jenkinson (1987) have found that Cu deficiency in the rat resulted in increased carbon tetrachloride-induced lipid peroxidation as indicated by expired ethane. Similarly Saari et al. (1990a) observed cnhanced ethane production in $\mathrm{Cu}$-deficient rats. Moreover the cardiovascular defects of $\mathrm{Cu}$ deficiency can be ameliorated by dietary supplementation with the exogenous antioxidants, t-butylhydroquinone (Johnson \& Saari, 1989) and dimethyl sulphoxide (Saari et al. 1990b).

Historically one of the earliest recognized signs of $\mathrm{Cu}$ deficiency, was the impaired glucose tolerance in animals observed by Keil \& Nelson (1934). More recently it was demonstrated that the diabetogenic effects of $\mathrm{Cu}$ deficiency were dependent on the type of carbohydrate fed to rats with fructose being more diabetogenic than glucose (Fields et al. 1984a). Although the extent of lipid peroxidation and other signs of $\mathrm{Cu}$ deficiency in the rat are also exacerbated by dietary fructose compared with glucose or starch (Fields et al. 1984b) it is unclear how impairment of antioxidant defence might be related to signs of $\mathrm{Cu}$ deficiency such as increased blood glucose, glucosuria, decreased insulin secretion and insulin-receptor bonding, lipogenesis and epididymal fat, intestinal hexose uptake, liver and diaphragm glycogen, and hepatic glucose-6-phosphatase (EC 3.1.3.9) activity as well as increases in serum triacylglycerols and cholesterol and hepatic glucose-6-phosphate dehydrogenase (EC 1.1.1.49) activity (see Sorenson, 1989). Cu deficiency can also increase the severity of STZ-induced diabetes (Cohen et al. 1982) and the susceptibility of the exocrine pancreas to oxidative damage (Dubick et al. 1989).

There is additional evidence from human studies of a link between $\mathrm{Cu}$ deficiency and diabetes. Decreased glucose tolerance was observed in two men during experimental $\mathrm{Cu}$ depletion $(0.78 \mathrm{mg} / \mathrm{d})$ but improved with $\mathrm{Cu}$ repletion $(6 \mathrm{mg} / \mathrm{d})$ beyond the glucose tolerance observed before the initiation of depletion (Klevay et al. 1986).

There also appears to be altered $\mathrm{Cu}$ metabolism in diabetes. In general STZ-induced diabetes increases $\mathrm{Cu}$ content associated with metallothionein of rat liver and kidney tissues (Uriu-Hare et al. 1988). The near normal hepatic $\mathrm{Cu}$ concentration found in the diabetic obese animal, however, is probably due to the opposing influences of the obese and diabetic conditions on the hepatic concentration of $\mathrm{Cu}$ (Donaldson et al. 1987). Nevertheless treatment with $\mathrm{Cu}, \mathrm{Zn}-\mathrm{SOD}$ and SOD mimetic $\mathrm{Cu}$ complexes can inhibit STZ- or alloxan-induced diabetes (Sorenson, 1989). It is possible, therefore, that increased $\mathrm{Cu}, \mathrm{Zn}$-SOD activity in the pancreatic $\beta$ cell offers greater protection against ROS.

Even though there appears to be higher $\mathrm{Cu}$ concentrations in some tissues of the diabetic rat, the $\mathrm{Cu}$ may not be biologically available. For example the formation of the highly stable polyol-Cu complex (Hamalainen \& Makinen, 1989) may increase $\mathrm{Cu}$ requirements in diabetes. Rat tissue levels of sorbitol are elevated by fructose consumption compared with starch or glucose consumption and $\mathrm{Cu}$ deficiency can lead to even higher levels of this polyol (Fields et al. 1989). The disruption of GSH metabolism in 
STZ-induced diabetes may also compromise the role of $\mathrm{Cu}$ in antioxidant defence. Recent in vitro work indicates that a $\mathrm{Cu}-\mathrm{GSH}$ complex is required to transfer $\mathrm{Cu}$ to the holoform of $\mathrm{Cu}, \mathrm{Zn}-\mathrm{SOD}$ (Ciriolo et al. 1990) and this requirement could explain the earlier work of Loven et al. (1986) who suggested a link between GSH metabolism and $\mathrm{Cu}, \mathrm{Zn}$-SOD in STZ-induced diabetes. Moreover, the glycation of $\mathrm{Cu}, \mathrm{Zn}$-SOD and its inactivation in diabetes (Taniguchi et al. 1989) may further impair antioxidant defences.

Recently Fields et al. (1991) have found that deferoxamine can ameliorate the pathology of $\mathrm{Cu}$ deficiency most probably by decreasing body Fe overload. It is well known that $\mathrm{Cu}$ deficiency can disrupt $\mathrm{Fe}$ transport and metabolism and it is possible that some of the anti-diabetic action of dietary $\mathrm{Cu}$ may be due to the alleviation of impaired mobilization of stored Fe.

In general serum $\mathrm{Cu}$ and caeruloplasmin levels are increased in IDDM and NIDDM patients (Mooradian \& Morley, 1987). It is probable that these increases reflect the greater inflammatory conditions in diabetes as caeruloplasmin is an acute phase reactant (DiSilvestro, 1990). Jones et al. (1988) have concluded that the increased caeruloplasmin-ferroxidase (EC 1.16.3.1) activity and Fe-bonding proteins in diabetic serum may be a response to oxidative stress. Certainly increased blood $\mathrm{Cu}$ levels do not necessarily reflect increased body Cu status (DiSilvestro, 1990). Sjogren et al. (1986) have found that the level of $\mathrm{Cu}$ in striated muscle was significantly lower in IDDM patients compared with healthy controls even though much higher levels of plasma $\mathrm{Cu}$ were observed in these patients compared with controls.

\section{ZINC}

High concentrations or doses of $\mathrm{Zn}$ are known to have antioxidant-like effects in in vitro systems and in vivo. Similarly, there is some evidence to suggest an increased oxidative stress in $\mathrm{Zn}$ deficiency but the precise role of $\mathrm{Zn}$ as an antioxidant has still to be elucidated (Bray \& Bettger, 1990). Two possible mechanisms are the protection of sulphydryl groups against oxidation and the inhibition of transition metal-catalysed production of ROS through induction of metallothionein (Fig. 2). The enzymic activity of $\mathrm{Cu}, \mathrm{Zn}-\mathrm{SOD}$, however, is unaffected by $\mathrm{Zn}$ status (Taylor et al. 1988).

Crystalline insulin contains $\mathrm{Zn}$ but the effect of $\mathrm{Zn}$ deficiency on impaired glucose tolerance or insulin secretion is controversial and remains unproven (Mooradian \& Morley, 1987). It has been suggested that the insulin-like effects of $\mathrm{Zn}$ in adipocytes involve the ability of $\mathrm{Zn}$ to modulate peroxide generation (May \& Contoreggi, 1982), but any effects of $Z_{\mathbf{n}}$ on insulin secretion are biphasic with higher concentrations impairing insulin secretion (Mooradian \& Morley, 1987). It is probable that the latter arises from the well known antagonistic effect of $\mathrm{Zn}$ supplements on $\mathrm{Cu}$ status.

Lower tissue levels of $\mathrm{Zn}$ have been reported in genetically obese ( $d b / d b$ and $o b / o b$ ) mice and (SHR-corpulent and obese Zucker) rats (Failla \& Micahelis, 1984; Kennedy et al. 1986; Donaldson et al. 1987). However, at least for the $d b / d b$ mouse, when results were expressed on an ash weight basis $\mathrm{Zn}$ levels were found to be normal and the low femur Zn.concentrations seen in $d b / d b$ mice appear to be primarily due to a generalized decrease in their bone mineral content (Donaldson et al. 1988). Chemically-induced diabetes also has little effect on tissue $\mathrm{Zn}$ concentrations (Levine et al. 1983).

Continuous intravenous infusion of glucose over $7 \mathrm{~d}$ in dogs greatly increased urinary $\mathrm{Zn}$, and hyperzincuria is a consistent observation among NIDDM (Kinlaw et al. 1983) 
and IDDM (Sjogren et al. 1986) patients. In the study of Sjogren et al. (1986) hyperzincuria was accompanied by large decreases in plasma $\mathrm{Zn}$ levels. Yet the level of $\mathrm{Zn}$ in muscle and erythrocytes was unaltered. As with $\mathrm{Cu}$, plasma $\mathrm{Zn}$ is a poor indicator of $\mathrm{Zn}$ status and the low plasma levels of IDDM patients are probably explained by increased inflammatory stress in these patients. It is possible that hyperzincuria reflects the higher turnover of lean body tissue in diabetes mellitus.

\section{MANGANESE}

$\mathrm{Mn}$ is an essential component of the antioxidant enzyme Mn-SOD found in cell mitochondria (Fig. 2). Activity of this enzyme is influenced by Mn status (Paynter, 1980). Other metalloenzymes containing $\mathrm{Mn}$ are the gluconeogenic enzymes, phosphoenolpyruvate carboxykinase ( $E C 4.1 .1 .32$ ), and pyruvate carboxylase ( $E C$ 6.4.1.1).

$\mathrm{Mn}$ deficiency in second-generation rats results in impaired gluconeogenesis in the neonatal period, abnormal glucose tolerance, low plasma insulin levels, low insulin output from the pancreas and depressed insulin synthesis (Baly et al. 1985). Acute Mn toxicity can also affect glucose homeostasis in the rat (Keen et al. 1985). The latter workers observed a rise in plasma glucose and glucagon and a decrease in plasma insulin concentration. These findings complement earlier work where $\mathrm{Mn}$ deficiency in guineapigs can cause impaired glucose utilization which can be reversed by $\mathrm{Mn}$ supplementation (Everson \& Shrader, 1968) and intra-uterine Mn deficiency results in atrophy of islet cells (Shrader \& Everson, 1968).

A number of studies have shown greatly elevated hepatic $\mathrm{Mn}$ levels in rats with STZ-induced diabetes (Failla \& Kiser, 1981; Bond et al. 1983) and excessive accumulation of $\mathrm{Mn}$ was found in fetuses of diabetic rat dams (Eriksson, 1984; Uriu-Hare et al. 1985). Elevated activities of arginase (EC 3.5.3.1), a Mn-dependent enzyme, was also found (Bond et al. 1983) and this may explain the increased rates of hepatic amino acid metabolism and urea synthesis which characterize insulin deficiency. These observations of increased $\mathrm{Mn}$ status in animal models of diabetes are also consistent with the findings of Loven et al. (1982, 1983) who reported increased tissue Mn-SOD activity in experimental diabetes. Results of blood analyses of diabetic patients are inconsistent and both low and high Mn levels have been reported (see Mooradian \& Morley, 1987).

\section{SELENIUM AND VITAMIN E}

The selenoenzyme GSH-Px protects against tissue damage caused by both hydrogen peroxide and lipid peroxides (Fig. 2). In the latter chain-breaking role the Se-dependent enzyme has a close metabolic relationship with the major lipid-soluble antioxidant, vitamin $\mathrm{E}$.

The activity of GSH-Px is increased in rat erythrocytes and kidney in both alloxan- and STZ-induced diabetes but, as with the other antioxidant enzymes, observed changes were inter alia tissue dependent (Dohi et al. 1988; Godin et al. 1988). Changes in activities of the non-Se-dependent glutathione-S-transferases ( $E C$ 2.5.1.18; GST) have also been reported (Murray \& Zalunzy, 1989) in experimental diabetes. In human studies there appears to be no consistent changes in blood GSH-Px activity in either IDDM or NIDDM (see Oberley, 1988). 
Although much work has centred on GSH and the GSH-requiring enzymes in diabetes, there is little information on Se status. There is one report of a higher mean serum Se level in IDDM children compared with healthy controls (Gebre-Medhin et al. 1984). Further cvidence for disturbances of Se metabolism in diabetes is provided by Dohi et al. (1988) who found increased serum Se levels in STZ-induced diabetic rats.

Asayama et al. (1986) studied the effect of Se deficiency and vitamin E deficiency on insulin secretory reserve and free-radical-scavenging systems in pancreatic islet cells. Glucose intolerance developed only in those rats with the combined Se and vitamin $\mathrm{E}$ deficiencies. Apart from the expected decrease in GSH-Px activities in various tissues with Se deficiency, Mn-SOD concentrations in islets were significantly lower than control levels in response to vitamin E. or Se deficiencies. The combined deficiency appeared to have an additive effect on Mn-SOD levels and it was suggested that decreases in Mn-SOD reflected decreased mitochondrial activity. These workers also confirmed the earlier observations of Grankvist et al. (1981) and Malaisse et al. (1982) on the low antioxidant status of pancreatic islet cells compared with other tissues. Levels of $\mathrm{Cu}, \mathrm{Zn}-\mathrm{SOD}$ and total SOD and especially GSH-Px in islets were the lowest among studied tissues.

A combined deficiency of vitamin $E$ and Se has also been shown to enhance the sensitivity of rats to STZ-induced diabetes (Slonim et al. 1983). Vitamin supplementation can protect rats from the diabetogenic action of alloxan and STZ (Slonim et al. 1983) and can decrease the incidence of diabetes in the spontaneously diabetic BB rats (Behrens et al. 1986). Platelet (Karpen et al. 1982) and hepatic (Higuichi, 1982) vitamin E levels are known to be depressed in STZ-induced diabetes. Furthermore diabetes-prone BB rats before the onset of diabetes have lower levels of vitamin $\mathrm{E}$ in adrenal gland, thymus and pancreas but not in plasma and other tissues compared with control BB rats (Behrens \& Madere, 1991). Work from the latter laboratory has indicated increased accumulation of tocopherols in serum and some other tissues from the diabetes-prone $\mathrm{BB}$ rats after the onsct of diabetes (Behrens et al. 1984).

Some clinical studies have shown higher vitamin $E$ concentrations in plasma platelets and adipose tissue of diabetic patients compared with normal controls (see Mooradian \& Morley, 1987). Vandewoude et al. (1987), however, have argued that apparent increases in plasma vitamin $E$ may result from altered plasma lipid transport capacity in diabetes. They found no differences in lipid-standardized plasma vitamin E (vitamin E:cholesterol ratio) levels among IDDM or NIDDM patients compared with respective age- and sex-matched controls.

Not all studies have shown increased platelet vitamin $E$ levels in clinical diabetes. Karpen et al. (1984) and Watanabe et al. (1984) have found evidence for vitamin E-deficient platelets in diabetic patients. Thus, Gisinger et al. (1990) have proposed the therapeutic potential of vitamin $E$ to alter platelet function in diabetes. Reports of studics to test the efficacy of vitamin $E$ indicate that platelet activity and eicosanoid production can be normalized by vitamin $E$ supplementation in experimental diabetes (Karpen et al. 1982; Gilbert et al. 1983) and in diabetic patients (Collette et al. 1988: Gisinger et al. 1988). A recent study has also demonstrated that vitamin $\mathrm{E}$ administration may decrease oxidative protein glycosylation in diabetic subjects independently of changes in plasma glucose (Ceriello et al. 1991). Increased non-enzymic protein glycosylation is another abnormality which occurs in diabetes and which may be involved in the long-term tissue complications of diabetes (Kennedy \& Baynes, 1984). 


\section{ASCORBIC ACID}

Ascorbic acid (AA) is a key component of antioxidant defence (Fig. 2) and is consumed most rapidly under oxidative stress (Niki et al. 1988). There is a well-established synergistic relationship between $A A$ and vitamin $E$ in the inhibition of lipid peroxidation in in vitro systems (Niki, 1987). The vitamin C (ascorbyl) radical formed by the reduction of vitamin $\mathrm{E}$ radical may be reduced back to $\mathrm{AA}$ by an NADH-dependent system. The ascorbyl radical is an intermediate in the reversible two-step oxidation process of AA to form dehydroascorbate (DHAA) and the latter oxidation product can be reduced back to AA with GSH and GR (Niki, 1991).

Numerous studies have suggested major disturbances of vitamin $C$ metabolism in experimentally-induced diabetes (Zebrowski \& Bhatnagar, 1979; Yew, 1983), diabetesprone rats (Behrens \& Madere, 1991) and in diabetic patients (Yue et al. 1990; Cunningham et al. 1991; Sinclair et al. 1991). In general there seems to be an impaired tissue AA storage in both NIDDM (Chen et al. 1983) and IDDM (Cunningham et al. 1991), although not all are in agreement (Schorah et al. 1988). In the study of Cunningham et al. (1991) after allowing for differences in dietary vitamin C intake, there was a mean storage AA deficit in mononuclear leucocytes (an indicator of tissue vitamin $\mathrm{C}$ status) of $50 \%$ in adults with IDDM compared with non-diabetics. There also appear to be increased serum DHAA:AA ratios and decreased serum AA in NIDDM patients compared with age-matched controls (Sinclair et al. 1991). These findings suggest that there is an increased oxidative stress and that vitamin $C$ uptake into tissues is impaired in diabetes mellitus. In vitro studies have shown that active transport of both AA and DHAA appear to be decreased by hyperglycaemia and insulin deficiency; DHAA and AA competing for uptake with glucose (Padh et al. 1985: Cunningham, 1988). Inhibition of uptake and, thus, recycling of ascorbyl radical and DHAA by NADH and GSH systems, may lead to increased formation of diketogluconic acid, a breakdown product of AA. Tolrestat, an aldose reductase inhibitor (Fig. 1), has been shown to elevate plasma AA in diabetic rats (Yue et al. 1989), while AA supplementation of diabetic patients lowered erythrocyte sorbitol levels (Vinson et al. 1989). Mechanisms for these effects are unknown at present but it is possible that there is an intimate relationship between the antioxidant GSH systems and vitamin C metabolism. Vitamin $\mathrm{C}$ has also been implicated in long-term complications of diabetes through effects of AA deficiency on collagen abnormalities (McLennan et al. 1988), immune function (Pecoraro \& Chen, 1987) and platelet activation (Sarji et al. 1979).

\section{CONCLUSIONS}

There is now strong evidence for a role for ROS in the development of experimentallyinduced diabetes and support for a disturbed oxidant-antioxidant balance as a predisposing factor in animal models is growing. Disturbances of micronutrient status may be a predisposing factor but how these observations in animal models relate to the aetiology of IDDM or NIDDM is presently unclear.

There is also some evidence for a role for ROS in diabetic complications in animal models and in diabetic patients. Whatever the precise role of oxidant damage in diabetes, a substantial body of evidence has accumulated to indicate major disturbances of antioxidant and micronutrient status in the diabetic state. 


\section{REFERENCES}

Asayama, K., Hayashibe, H., Dobashi, K., Niitsu, T., Miyao, A. \& Kato, K. (1989). Antioxidant enzyme status and lipid peroxidation in various tissues of diabetic and starved rats. Diabetes Research 12, 85-91.

Asayama, K.. Kooy. N. W. \& Burr, I. M. (1986). Effect of vitamin E deficiency and selenium deficiency on insulin secretory reserve and free radical scavenging systems in islets: Decrease of islet manganosuperoxide dismutase. Journal of Laboratory and Clinical Medicine 107, 459-464.

Balevska, P. S., Russanov, E. M. \& Kasabova, T. A. (1981). Studies of lipid peroxidation in rat liver by copper deficiency. International Journal of Biochemistry 13, 489-493.

Baly, D. L., Keen, C. L.. Curry, D. L. \& Hurley, I. S. (1985). Effects of manganese deficiency on carbohydrate metabolism. In Trace Elements in Man and Animals (TEMA 5), pp. 254-258 [C. F. Mills. I. Bremmer and K. J. Chesters, cditors]. Slough: Commonwealth Agricultural Bureaux.

Baynes, J. W. (1991). Role of oxidative stress in development of complications in diabctes. Diahetes $\mathbf{4 0}$, 405-412.

Behrens, W. A. \& Madere, R. (1991). Vitamin C and vitamin E: status in the spontaneously diabetic BB rat before the onset of diabetes. Metabolism 40, 72-76.

Bchrens, W. A., Scott, F. W., Madere. R. \& Trick, K. D. (1984). Increased plasma and tissuc levels of vitamin $E$ in the spontaneously diabetic BB rat. Life Sciences 35. 199-206.

Behrens, W. A., Scott, F. W., Madere, R., Trick, K. \& Hanna, K. (1986). Effect of dietary vitamin E on the vitamin $\mathrm{E}$ status in the BB rat during development and after the onset of diabetes. Annals of Nutrition \& Metabolism 30, 157-165.

Biemond, P.. Swaak, A. J. G., Eijk, H. G. \& Foster. J. F. (1988). Superoxide dependent iron release from ferritin in inflammatory diseases. Free Radical Biology \& Medicine 4, 185-198.

Bond, J. S., Faile, M. L. \& Unger, D. F. (1983). Elevated manganese concentration and arginase activity in livers of streptozotocin-induced diabetic rats. Journal of Biological Chemistry 258, 8004-8009.

Bray. T. M. \& Bettger. W. J. (1990). The physiological role of zinc as an antioxidant. Free Radical Biology' \& Medicine 8. 281-291.

Cand. F. \& Verdetti, J. (1989). Superoxide dismutase, glutathione peroxidase. catalase and lipid peroxidation in the major organs of the ageing rats. Free Radical Biology \& Medicine 7, 59-63.

Ceriello, A., Guigliano, D., Quatraro, A., Donzella, C., Dipalo. G. \& Lefebure, P. J. (1991). Vitamin E reduction of protein glycosylation in diabetes. Diabetes Care 14, 68-72.

Chen, M. S. . Hutchinson, M. L., Pecoraro, R. E., Lee, W. Y. \& Labbe, R. F. (1983). Hyperglycemia induced intracellular depletion of ascorbic acid in human mononuclear leukocytes. Diabetes 32, 1078-1081.

Ciriolo, M. R.. Desideri, A., Paci, M. \& Rotilio, R. (1990). Reconstitution of Cu.Zn-superoxide dismutase by the Cu (1)-glutathione complex. Journal of Biological Chemistry 265, 11030-11034.

Cohen, A. M. Teitclbaum, A., Miller, E. Ben-Tor, V.. Hirt, R. \& Fields, M. (1982). The effect of copper deficiency on carbohydrate metabolism in rats. Israel Journal of Medical Science 18, 840-844.

Cole, H. S., Lopez, R. \& Cooperman. J. M. (1976). Riboflavin deficiency in children with diabetes mellitus. Acta Diabetologica Latina 13, 25-29.

Collette, C., Pares-Herbute, N.. Monnier, L. \& Cartny. E. (1988). Platelet function in type I diabetes: Effects of supplementation with large doses of vitamin E. American Journal of Clinical Nutrition 47, 256-261.

Costagliola. C. Juliano, G., Menzione, M.. Nesti, A.. Simonelli, F. \& Rinaldi, E. (1988). Systemic human diseases as oxidative risk factors in cataractogenesis. 1. Diabetes. Ophthalmic Research 20, 308-316.

Cunninghtm, J. J. (1988). Altered vitamin C transport in diabetes mellitus. Medical Hypotheses 26, 263-265.

Cunningham. J. J., Ellis, S. L.. McVeigh, K. L., Levine, R. E. \& Calles-Escandon, J. (1991). Reduced mononuclear leukocyte ascorbic acid content in adults with insulin-dependent diabetes mellitus consuming adequate dietary vitamin C. Metabolism 40, 146-149.

DiSilvestro. R. A. (1990). Influence of dietary copper. copper injections and inflammations on rat serum ceruloplasmin activity levels. Nutrition Research 10, 355-358.

Dohi, T., Kawamura, K.. Morita. K., Okamoto. H. \& Tsujimoto, A. (1988). Alterations of the plasma selenium concentrations and the activities of tissue peroxide metabolism enzymes in streptozotocin-induced diabetic rats. Hormone and Metabolic Research 20, 671-675.

Donaldson, D. L.. Smith. C. C. \& Kok, E. (1987). Effects of obesity and diabetes on tissue zinc and copper concentrations in the Zucker rat. Nutrition Research 7, 393-399.

Donaldson, D. L., Smith. C. C., Walker, M. S. \& Rennert, O. M. (1988). Tissue zinc and copper levels in diabetic $\mathrm{C} 57 \mathrm{BL} / \mathrm{KsJ}(\mathrm{db} / \mathrm{db})$ mice fed a zinc-deficient diet: Lack of evidence for specific depletion of tissue zine stores. Journal of Nutrition 118, 1502-1508. 
Drash, A. L., Rudert, W. A., Borquaye, S., Wang, R. \& Lilberman, I. (1988). Effect of probucol and development of diabetes mellitus in BB rats. American Journal of Cardiology 62, 27B-30B.

Dubick, M. A., Yu, G. S. M. \& Majumdar, A. P. N. (1989). Morphological and biochemical changes in the pancreas of the copper-deficient female rat. Journal of Nutrition 119, 1165-1172.

Eriksson, U. J. (1984). Diabetes in pregnancy: Retarded fetal growth congenital malformation and fetomaternal concentrations of zinc, copper and manganese in the rat. Journal of Nutrition 114, 477-484.

Everson, G. J. \& Shrader, R. E. (1968). Abnormal glucose tolerance in manganese deficient guinea pigs. Journal of Nutrition 94, 89.94.

Failla, M. L. \& Kiser, R. A. (1981). Altered tissue content and cytosol distribution of trace metals in experimental diabetes. Journal of Nutrition 111, 1900-1909.

Failla, M. J. \& Micahelis, D. M. (1984). Decreased tissue concentrations of essential trace metals in the obese rat. Federation Proceedings 43, 667 Abstr.

Fields, M., Ferretti, R. J., Smith, J. C. \& Reiser, S. (1984a). Impairment of glucose tolerance in copper-deficient rats: Dependency on the type of carbohydrate. Journal of Nutrition 114, 393-397.

Fields, M., Ferretti. R. J., Smith. J. C. \& Reiser, S. (1984b). Interaction between dietary carbohydrate and copper nutriture on lipid peroxidation in rat tissues. Biological Trace Element Research 6, 379-391.

Fields, M., Lewis, C. G. \& Beal, T. (1989). Accumulation of sorbitol in copper deficiency: Dependency on gender and type of dietary carbohydrate. Metabolism 38, 371-375.

Ficlds, M., Lewis, C. G., Lure, M. D., Burns, W. A. \& Antholine, W. E. (1991). The severity of copper deficiency can be ameliorated by deferoxamine. Metabolism 40, 105-109.

Fricker, J., Le Moel, G. \& Apfelbaum, M. (1990). Obesity and iron status in menstruating women. American Journal of Clinical Nutrition 52, 863-866.

Gebre-Medhin, M., Ewald, U., Platin, L.-O. \& Tuvemo, T. (1984). Elevated serum selenium in diabetic children. Acta Paediatrica Scandinavica 73, 109-114.

Gebre-Medhin. M., Ewald, U., Platin, L.-O., Tuvemo, T. \& Vessby, B. (1982). Selenium and lipoprotein metabolism in diabetogenic children. In Proceedings of the 11th Congress of the International Diabetes Federation, p. 206 [K. G. G. M. Alberti, T. Ogada, J. A. A. Alouch and E. N. Mngola, editors]. Amsterdam: Excerpta Medica.

Georgieff, M. K., Landon, M. B., Mills, M. M. Hedlund, B. E., Faassen, A. E., Schmidt, R. L., Ophoven, J. J. \& Widness, J. A. (1990). Abnormal iron distribution in infants of diabetic mothers: Spectrum and maternal antecedents. Journal of Pediatrics 117, 455-461.

Gilbert, V., Zebrowski, E. \& Chan, A. (1983). Differential effects of megavitamin E on prostacyclin and thromboxane synthesis in streptozotocin-induced diabetic rats. Hormone and Metabolic Research 15, 320-325.

Gillery, P., Monboisse, J.-C., Maquart, F.-X. \& Borel, J.-P. (1989). Does oxygen free radical increased formation explain long term complications of diabetes mellitus? Medical Hypotheses 29, 47-50.

Gisinger, C.. Jeremy. J., Speiser, P.. Mikhailidis, D., Dandona, P. \& Schernthaner, G. (1988). Effect of vitamin $\mathrm{E}$ supplementation on platelet thromboxane $\mathrm{A}_{2}$ production in type I diabetic patients. Diabetes 37 , $1260-1264$.

Gisinger, C., Watanabe. J. \& Colwell, J. A. (1990). Vitamin E and platelet eicosanoids in diabetes mellitus. Prostaglandins, Leukotrines and Essential Fatty Acids 40, 169-176.

Godin, D. V., Wohaieb, S. A., Garnett, M. E. \& Goumeniouk, A. D. (1988). Antioxidant enzyme alterations in experimental and clinical diabetes. Molecular and Cellular Biochemistry 84, 223-231.

Grankvist, K., Marklund, S. L. \& Taljedal, I.-B. (1981). CuZn-superoxide dismutase, Mn-superoxide dismutase, catalase and glutathione peroxidase in pancreatic islets and other tissues in the mouse. Biochemical Journal 199, 393-398.

Halliwell, B. (1987). Oxidants and human disease - some new concepts. FASEB Journal 1, 358-364.

Hamalainen, M. M. \& Makinen, K. K. (1989). Polyol-mineral interactions in the diet of the rat with special reference to the stabilities of polyol-metal complexes. Nutrition Research 9, 801-811.

Hellerstrom, C.. Andersson, A., Sandler, S. \& Swenne. I. (1986). Mechanisms of destruction and repair of the pancreatic B cell. Transplantation Proceedings 18, 1509-1512.

Higuichi, Y. (1982). Lipid peroxides and $\alpha$-tocopherol in rat streptozotocin-induced diabetes mellitus. Acta Medica Okayama 36, 165-175.

Hunt, J. V. \& Wolff, S. P. (1990). Is glucose the sole source of tissue browning in diabetes mellitus? FEBS Letters 269, 258-260.

Jain, S. K., Levine, S. I., Duett. J. \& Hollier, B. (1990). Elevated lipid peroxidation levels in red blood cells of strepozotocin-treated diabetics rats. Metabolism 39, 971-975. 
Jain. S. K., McVie, R., Duett, J. \& Herbst, J. J. (1989). Erythrocyte membrane lipid peroxidation and glycosylated hemoglobin diabetes. Diabetes 38, 1539-1543.

Johnson, W. T. \& Evans, G. W. (1984). Effects of the interrelationship between dictary protcin and minerals on tissue content of trace metals in streptozotocin-diabetic rats. Journal of Nutrition 114, 180-190.

Johnson. W. T. \& Saari, J. T. (1989). Dietary supplementation with t-butylhydroquinone reduces cardiac hypertrophy and ancmia associated with copper deficiency in rats. Nutrition Research 9, 1355-1362.

Jones. A. F. Winkles, J. W.. Jennings. P. E., Florkowski. C. M. . Lunec, J. \& Barnett. A. A. (1988). Serum antioxidant activity in diabetes mellitus. Diabetes Research '7, 89-92.

Jongkind, J. F., Verkerk, A. \& Baggen, R. G. A. (1989). Glutathione metabolism of human vascular endothelial cells under peroxidative stress. Free Radical Biology \& Medicine 7, 507-512.

Kaji. H., Kurasaki, M., Ito, K., Saito, T. Saito. K.. Niioka. T., Kojima. Y.. Ohsaki. Y., Ide, H. \& Tsuji, M. (1985). Increased lipoperoxide value and glutathione peroxidasc activity in blood plasma of type 2 (non-insulin-dependent) diabetic women. Klinisehl Wochenschrift 63, 765-768.

Karpen, C., Cataland, S., ODorisio, T. \& Panganamala, R. (1984). Interrelation of platelet vitamin E and thromboxane synthesis in type I diabetes mellitus. Diabetes 33, 239-243.

Karpen, C. W., Pritchard, K. A., Arnold, J. H. Cornwell. D. G. \& Panganamala. R. V. (1982). Restoration of prostacyclin/thromboxane $\mathrm{A}_{2}$ balance in the diabetic rat. Influence of dietary vitamin $\mathrm{E}$. Diabetes $\mathbf{3 1}$. 947-951.

Kcen. C. I.., Baly, D. I.., Tamai, K. T. \& Lonnerdal. B. (1985). Influcnce of manganese on glucose metabolism. In Trace Elements in Man and Animals (TEMA 5), pp. 258-261 [C. F. Mills, I. Bremner and K. J. Chesters, editors]. Slough: Commonwealth Agricultural Bureaux.

Keil, H. L. \& Nelson. V. E. (1934). The role of copper in carbohydrate metabolism. Journal of Biological Chemistry 106, 343-350.

Kennedy, L. \& Baynes, Y. W. (1984). Von-enzymatic glycosylation and the chronic complications of diabetes: An overview. Diaberologia 26, 93-98.

Kennedy. M. L., Failla, M. L. \& Smith. J. O. (1986). Influence of genetic obesity on tissue concentrations of zinc, copper. manganese and iron in mice. Journal of Nurrition 116, 1432-1441.

Kinlaw. W. B., Levine, A. S. . Morley, J. E.. Silvis, S. E. \& McClain. (. J. (1983). Abnormal zinc metabolism in type Il diabetes mellitus. American Journal of Medicine 75, 27.3-277.

Klevay. L. M. . Canfield. W. K., Gallagher, S. K., Henriksen, L. K., Lukaski, H. C., Bolonchuk. W., Johnson, L. A. K., Milne. D. B. \& Sandstead. H. H. (1986). Decreased glucose tolerance in two men during experimental copper depletion. Nutrition Reports International 33, 371-382.

Lawrence. R. A. \& Jenkinson, S. G. (1987). Effects of copper deficiency on carbon tetrachloride induced lipid peroxidation. Joumal of L aboratory and Cinical Medicine 109, 134-140.

Levine. A. S., McClain. C. J.. Handwerger. B. S.. Brown, D. M. \& Morlcy. J. E. (1983). Tissue zinc status of genetically diabetic and streptorotocin-induced diabetic mice. American Journal of Clinical Nurition 37. $382-386$

Loven. D. P.. Oberley, L. W., Schedl, H. P. \& Wilson. H. D. (1983). Superoxide dismutase activities in jejunum and kidney of diabetic rats treated with insulin and glutathione. In Oxy-Radicals and Their Scavenger Systems, vol. 2. pp. 17-21 [R. A. Greenwald and G. Cohen, editors]. New York: Elscrier.

Loven, D. P., Schedl, H. P.. Oberley, L. W., Wilson, H. D., Bruch, L. \& Niehaus, C. N. (1982). Superoxide dismutase activity in the intestinal mucosa of the streptozotocin-diabetic rat. Endocrinology 111. 737-742.

Loven, D. P., Schedl, H., Wilson, H., Daabees, T. T., Stegink, L. D., Diekus. M. \& Oberley, L. (1986). Effect of insulin and oral glutathione on glutathione levels and supcroxide dismutase activities in organs of rats with streptozotocin-induced diabetes. Diabetes 35, 50)3-507.

Lynch. S. M. \& Strain. J. J. (1989). Increased hepatic lipid peroxidation with methionine toxicity in the rat. Free Radical Research Communications 5, 221-226.

McDermott. B. M.. Strain. J. J. \& Flatt, P. R. (1991). Effects of copper deficiency and induction of streptozotocin (STZ)-diabetes on trace element mineral status in the rat. Procecdings of the Nutrition Society' (In the Press).

McIennan, S., Yuc, D. K.. Fisher, E. Caprogreco, C., Heffernan, S., Ross, G. R. \& Turtle. J. R. ( I988). Deficiency of ascorbic acid in experimental diabetes: relationship with collagen and polyol pathway abnormalitics. Diabetes 37, 359-361.

Malaisse, W'. J., Malaisse-Lagal, F.. Senor, A. \& Pipeleers. D. G. (1982). Determinants of the selective toxicity of alloxan to the pancreatic $\beta$-cell. Procedings of the National Academy of Sciences USA 79. 927-930. 
Matkovics, B., Varga, Sz. I., Szabo, L. \& Witas, H. (1982). The effect of diabetes on the activities of the peroxide metabolism enzymes. Hormone and Metabolic Research 14, 77-79.

May, J. M. \& Contoreggi, C. S. (1982). The mechanism of the insulin-like effects of ionic zinc. Journal of Biological Chemistry 257, 4362-4368.

Merkel, P. A., Simonson, D. C., Amiel, S. A., Plewe, G., Sherwin, R. S. Pearson, H. A. \& Tamborlane, W. V. (1988). Insulin resistance and hyperinsulinemia in patients with thalassemia major treated by hypertransfusion. New England Journal of Medicine 318, 809-814.

Mertz, W. (1982). Trace minerals and atherosclerosis. Federation Proceedings 41, 2807-2812.

Micozzi, M. S.. Albanes, D. \& Stevens, R. G. (1989). Relation of body size and composition to clinical biochemical and hematologic indices in US men and women. American Journal of Clinical Nutrition $\mathbf{5 0}$, $1276-1281$

Mooradian. A. D. \& Morley, J. E. (1987). Micronutrient status in diabetes mellitus. American Journal of Clinical Nutrition 45, 877-895.

Mullarkey, C. J., Edelstein. D. \& Brownlee, M. (1990). Free radical generation by carly glycation products: A mechanism for accelerated atherogenesis in diabetes. Biochemical and Biophysical Research Communications 173, 932-939.

Murakami, K., Kondo, T.. Ohtsuka, Y.. Fujiwara, Y., Shimada, M. \& Kawakami, Y. (1989). Impairment of glutathione metabolism in erythrocytes from patients with diabetes mellitus. Metabolism 38, 753-758.

Murray, M. \& Zaluzny, L. (1989). Comparative effects of genctic obesity and streptozotocin-diabctes on rat liver cytosolic glutathione-S-transferase activities. Nutrition Research 9, 1151-1160.

Niki, E. (1987). Interaction of ascorbate and $\alpha$-tocopherol. Annals of New York Academy of Sciences 498, 186-199.

Niki. E. (1991). Vitamin C as an antioxidant. In Selected Vitamins, Minerals and Functional Consequences of Maternal Malnutrition. World Review of Nutrition \& Dietetics, vol. 64, pp. 1-30 [A. P. Simopoulos, editor]. Basel: Karger.

Niki, E., Yamamoto, Y., Takahashi, M., Yamamoto, K., Yamamoto, Y., Komuro, E., Miki, M., Yasuda, H. \& Mimo, M. (1988). Free radical-mediated damage of blood and its inhibition by antioxidants. Vitumins, Kyoto 62, 200.

Nomikos, 1. N., Prowse, S. J., Carotenuto, P. \& Lafferty, K. J. (1986). Combined treatment with nicotinamide and desferrioxamine prevents islet allograft destruction in NOD mice. Diabetes 35, 1302-1304.

Oberley, L. W. (1988). Free radicals and diabetes. Free Radical Biology \& Medicine 5, 113-124.

Okamoto, H. (1983). Insulin biosynthesis under physiological and pathological conditions. Gunma Symposia on Endocrinology, vol. 20, pp. 21-37. Tokyo: Center for Academic Publications.

Padh, H., Subramoniam, A. \& Aleo, J. J. (1985). Glucose inhibits cellular ascorbic acid uptake by fibroblasts in vitro. Cell Biology International Reporis $9,531-538$.

Paynter, D. I. (1980). The role of dietary copper, manganese, selenium and vitamin $E$ in lipid peroxidation in tissues of the rat. Biological Trace Element Research 2, 121-135.

Pecoraro, R. E. \& Chen, M. S. (1987). Ascorbic acid metabolism in diabetes mellitus. Annals of New York Academy of Sciences 498, 248-258.

Phclps, G., Chapman, I., Hall, P., Braund, W. \& Mackinnon, M. (1989). Prevalence of genetic haemochromatosis among diabetic patients. Lancet ii, 233-234.

Powell. L. W. (1985). Haemochromatosis and related iron storage diseases. In Liver and Biliary Disease, pp. 936-982 [R. Wright, G. H. Millward-Sadler. K. G. M. M. Alberti and S. Karran, editors]. London: Balliere-Tindall.

Saari. J. T., Dickerson, F. D. \& Habib, M. P. (199()a). Ethane production in copper deficient rats. Proceeding.s of the Socicty for Experimental Biology and Medicine 195, 30-33.

Saari, J. T., Recves, P. G.. Noodevier, B., Hall, C. B. \& Lukaski, H. C. (1990b). Cardiovascular but not renal effects of copper deficiency are inhibited by dimethyl sulfoxide. Nutrition Research 10, 467-477.

Sarji, K. E., Kleinfelder, J., Brewington, P.. Gonzalez, J., Hempling, H. \& Colwell, J. A. (1979). Decreased platelet vitamin $\mathrm{C}$ in diabetes mellitus: possible role in hyperaggregation. Thrombosis Research 15. 6.39-650.

Sato, Y., Hotta, N., Sakamoto, N., Matsuoka, S., Ohiski, N. \& Yagi, K. (1979). Lipid peroxide level in plasma of diabetic patients. Biochemical Medicine 21, 104-107.

Schorah, C. J., Bishop, N.. Wales, J. K.. Hansbro. P. M. \& Habibzadeh, N. (1988). Blood vitamin C concentrations in patients with diabetes mellitus. International Journal of Vitamin \& Nutrition Research 58 , 312-318.

Shrader, R. E. \& Everson, G. J. (1968). Pancreatic pathology in manganese-deficient guinea pigs. Journal of Nutrition 94, 209-218. 
Sinclair, A. J., Girling, A. J., Gray, L., Le Guen, C., Lunec. J. \& Barnett, A. H. (1991). Disturbed handling of ascorbic acid in diabetic patients with and without microangiopathy during high dose ascorbate supplementation. Diabetologia 34, 171-175.

Sjogren, A., Edvinsson, L., Floren, C.-H. \& Abdulla, M. (1986). Zinc and copper in striated muscle and body fluids from subjects with diabetes mellitus Type 1. Nutrition Research 6, 147-154.

Slonim, A. E., Surber, M. L.. Page, D. L.. Sharp, R. A. \& Burr, I. M. (1983). Modification of chemically induced diabetes in rat by vitamin E. Journal of Clinical Investigation 71, 1282-1288.

Sorenson, J. R. J. (1989). Copper complexes offer a physiological approach to treatment of chronic diseases. In Progress in Medicinal Chemistry, vol. 26, pp. 437-568 [G. P. Ellis and G. B. West, editors]. New York: Elsevier.

Strain, J. J., Hannigan, B. M. \& McKenna, P. G. (1991). The pathophysiology of oxidant damage. Journal of Biomedical Sciences 2, 19-24.

Strain, J. J. \& Lynch, S. M. (1990). Excess dietary methionine decreases indices of copper status in the rat. Annals of Nutrition \& Metabolism 43, 93-97.

Stremmel, W.. Niederau, C., Berger, M.. Kley, H.-K., Kruskemper, H.-L. \& Strohmeyer, G. (1987). Abnormalities in estrogen, androgen, and insulin metabolism in idiopathic hemochromatosis. Annals of New York Academy of Sciences 498, 209-223.

Taniguchi, N., Arai, K. \& Kinoshita, N. (1989). Glycation of copper/zinc superoxide dismutase and its inactivation: identification of glycated sites. Methods in Enzymology 48, 570-581.

Taylor, C. G., Bettger, W. J. \& Bray. T. M. (1988). Effects of dictary zinc or copper deficiency on the primary frec radical defense system in rats. Journal of Nutrition 118, 61.3-621.

Uriu-Hare, J. Y., Stern, J. S. \& Keen. C. L. (1988). The effect of diabetes on the molecular localization of maternal and fetal zinc and copper metalloprotein in the rat. Biological Trace Element Research 18, 71--79.

Uriu-Hare, J. Y., Stern, J. S., Reaven, G. M. \& Keen, C. L. (1985). The effect of maternal diabetes on trace element status and fetal development in the rat. Diabetes 34, 1031-1040.

Uzel, N.. Sivas. A., Uysal, M. \& Oz, H. (1987). Erythrocyte lipid peroxidation and glutathione peroxidase activities in patients with diabetes mellitus. Hormonal Metabolism Research 19, 89-90.

Vandewoude, M. G., van Gaal, L. F.. Vandewoude, M. F. \& De Lceuw, I. H. (1987). Vitamin E status in normocholesterolemic and hypercholesterolemic diabetic patients. Acta Diabetologica Latina 24, 133-139.

Vinson, J. A., Staretez, M. E., Bose, P., Kassm, H. M. \& Basalyga, B. S. (1989). In vitro and in vivo reduction of erythrocyte sorbitol by ascorbic acid. Diabetes 38, 1036-1041.

Wachnik, A., Biro, G.. Gergely. A., Gaal, O. \& Antal, M. (1989). Hepatic lipid peroxidation in copper deficient rats. Nutrition Reports International 40, 2327-2333.

Watanabe, J., Umeda. F., Wakasugi, H. \& Ibayashi. H. (1984). Effect of vitamin E on platelet aggregation in diabetes mellitus. Thrombosis \& Haemostasis 51, 313-316.

Wohaicb, S. A. \& Godin, D. V. (1987). Starvation-related alterations in free radical tissue defense mechanisms in rats. Diuberes 36, 169-173.

Yeh, L.-A. \& Ashton, M. A. (1990). The increase in lipid peroxidation in diabetic rat lens can be reversed by oral sorbinil. Metabolism 39, 619-622.

Yew, M. S. (1983). Effect of streptozotocin diabetes on tissue ascorbic acid and dehydroascorbic acid. Hormone and Metabolic Research 15, 158.

Yue, D. K., McLennan, S.. Fisher, E., Heffernan, S., Capogreco, C., Ross, G. R. \& Turtle, J. R. (1989). Ascorbic acid metabolism and the polyol pathway in diabetes. Diabetes 38, 257-261.

Yue, D. K., McLennan, S., McGill, M., Fisher, E., Heffernan, S., Capogreco, C. \& Turtle. J. R. (1990). Abnormalities of ascorbic acid metabolism and diabetic control: Differences between diabetic patients and diabetic rats. Diabetes Research and Clinical Practice 9, $239-244$.

Zebrowski. E. J. \& Bhatnagar, P. K. (1979). Urinary excretion pattern of ascorbic acid in streptozotocin diabetic and insulin treated rats. Pharmacological Research Communications 11, 95-103. 